\title{
Short-Term Results of Robotic versus Laparoscopic Right Hemicolectomy with Complete Mesocolic Excision
}

\section{Robotik Cerrahiye Karșı Laparoskopik Komplet Mezokolik Eksizyon ile Sağ Hemikolektominin Kısa Dönem Sonuçları}

\author{
(1) Erol Pișkin1, (1) Muhammet Kadri Çolakoğlul, (1) Volkan Oterl, (1) Yiğit Mehmet Özgünl, (D) Osman Aydınl, \\ (D) Erdal Birol Bostanci2
}

IAnkara City Hospital, Clinic of Gastroenterological Surgery, Ankara, Turkey

2Ankara City Hospital SUAM, Clinic of Gastroenterological Surgery, Ankara, Turkey

\begin{abstract}
Objective: Despite oncological and pharmacological developments, the main treatment for cancer of the gastrointestinal system is surgery. Complete mesocolic excision (CME) is recommended owing to the importance of margin negativity of the specimen after mesoresection of the gastrointestinal organs. The aim of this study was to present our initial experience of performing minimally invasive CME in right-sided colon cancer and compare the short-term results of patients who underwent laparoscopic and robotic surgery.

Method: This retrospective study included patients who underwent laparoscopic and robotic right hemicolectomy with CME for colon cancer at our clinic between March 2019 and December 2020.

Results: A total of 18 patients who underwent eight robotic and 10 laparoscopic surgeries were included in the study. No significant difference in the demographic data distribution of the patients was found between the robotic and laparoscopic CME groups. When the operative and postoperative data were compared between the groups, no significant difference in intraoperative bleeding volume, oral onset time, flatus time, number of metastatic lymph nodes, number of lymph nodes removed, and tumor grade were noted between the groups. The operation time in the robotic CME group was longer than that in the laparoscopic CME group, and the difference was significant.

Conclusion: Based on the short-term follow-up results, we believe that CME of right colon tumors can be safely performed robotically or laparoscopically without any disadvantage.
\end{abstract}

Keywords: Right hemicolectomy, robotic, laparoscopic, complete mesocolic excision

\section{öz}

Amaç: Tüm onkolojik ve farmakolojik gelișmelere rağmen gastrointestinal sistem kanserinde tedavinin temeli cerrahidir. Tam mezokolik eksizyon (CME), gastrointestinal organlar için mezorezeksiyon sonrası gösterilen örnek marjı negatifliğinin önemi açısından önerilmektedir. Bu çalıșmanın amacı, sağ kolon kanserinde minimal invaziv CME'mizin ilk deneyimini sunmak ve laparoskopik ve robotik cerrahi geçiren hastaların kısa dönem sonuçlarını karșılaștırmaktır. Yöntem: Bu çalıșma retrospektif olarak planlandı. Kliniğimizde Mart 2019 - Aralık 2020 tarihleri arasında kolon kanseri nedeniyle CME ile laparoskopik ve robotik sağ hemikolektomi uygulanan hastalar çalışmaya dahil edildi.

Cite as: Pișkin E, Çolakoğlu MK, Oter V, Özgün YM, Aydın O, Bostancı EB. Short-Term Results of Robotic versus Laparoscopic Right Hemicolectomy with Complete Mesocolic Excision.IKSSTD 2021;13(2):136-43

๑Copyright 2021 by the Istanbul Kanuni Sultan Süleyman Training and Research Hospital / Medical Journal of Istanbul Kanuni Sultan Suleyman published by Galenos Publishing House. ๑Telif Hakkı 2021 Isstanbul Kanuni Sultan Süleyman Eğitim ve Araștırma Hastanesi / İstanbul Kanuni Sultan Süleyman Tıp Dergisi, Galenos Yayınevi tarafindan basılmıștır. 
Bulgular: CME ile 8 robotik ve 10 laparoskopik sağ hemikolektomi yapılan toplam 18 hasta çalışmaya dahil edildi. Robotik ve laparoskopik CME grupları karşılaştırıldığında hastaların demografik verileri (yaş, cinsiyet, VKi, ASA, tümör lokalizasyonu) dağlımları arasında istatistiksel olarak anlamlı bir fark bulunmadı. Operatif ve postoperatif veriler iki grup arasında karșılaștıııldığında, per-operatif kanama, oral bașlama zamanı, ilk flatus zamanı, metastatik lenf nodu sayısı, çıkarılan lenf nodu sayısı ve tümör grade'si açısından istatistiksel olarak anlamlı bir fark yoktu, robotik cerrahi grubunun operasyon süresi laparoskopik gruptan daha uzun olduğu gözlendi ve bu fark istatistiksel olarak anlamlı bulundu $(p=0,04)$.

Sonuç: Sağ kolon tümörleri için CME konseptinin, kısa süreli takipimize dayanarak, herhangi bir dezavantaj olmaksızın robotik veya laparoskopik olarak güvenle uygulanabileceğine inanıyoruz.

Anahtar kelimeler: Sağ hemikolektomi, robotik, laparoskopik, komplet mezokolik eksizyon

\section{INTRODUCTION}

Despite oncological and pharmacological developments, the basis of treatment of cancer of the gastrointestinal system is surgery. There have been many developments in the surgical treatment of colon and rectal cancer. Total mesorectal excision (TME), which was described by Heald in 1982, was shown to improve the oncological results in rectal cancer and was accepted as a gold standard, especially because reduction in the local recurrence rate was achieved ${ }^{(1)}$. TME basically consists of three main elements, namely, ligation of the main vascular pedicle that feeds the tumor, sharp dissection at the embryological margins, and obtaining an adequate distal surgical margin. High local recurrence rates were recorded in patients who underwent insufficient and low-quality TME (2).

In some recent studies, considering the importance of the mesentery that supplies the organ resected because of malignancy, reduction of local recurrence, increase in the number of lymph nodes, and increase in margin negativity of the specimen have been observed after mesoresection of organs such as the pancreas, stomach, and esophagus ${ }^{(3-5)}$. Considering the concept of TME for mesorectal dissection, its benefit for local recurrence is recognized, but some studies have reported that it has no effect on distant metastasis $(6,7)$.

Similar to TME, complete mesocolic excision (CME) in colon cancer was first described by Hohenberger et al. ${ }^{(8)}$. CME consists of mobilization of the visceral fascia, central ligation of the vessels feeding the tumor, and extraction of the specimen with adequate surgical margins. Based on metaanalyses of CME and non-CME for right-sided colon tumors, CME is more advantageous in terms of disease-free survival (DFS), disease-specific survival, and local recurrence ${ }^{(9)}$. A meta-analysis of techniques revealed that minimally invasive techniques are more advantageous in terms of DFS and overall survival (OS) when comparing laparoscopic and conventional CME ${ }^{(10)}$. Spinoglio et al. ${ }^{(11)}$ reported that both methods were safe and applicable based on the results of a comparison between robot-assisted and laparoscopic CME and that there was no significant difference between the two methods in terms of DFS and OS.

Thus, this study aimed to present our initial experience of performing minimally invasive CME in right-sided colon cancer and compare the short-term results of patients who underwent laparoscopic and robotic surgery.

\section{METHOD}

This single-center retrospective study included patients who underwent laparoscopic and robotic right hemicolectomy with CME for colon cancer at our clinic between March 2019 and December 2020. Written and verbal consents were obtained from all patients before surgery.

The patients' characteristics, such as age, sex, American Society of Anesthesiologists (ASA) score, body mass index (BMI), previous surgeries, and tumor location, were recorded. Intraoperative data included blood loss, anastomosis type, operation time, beginning of oral intake, flatus time, length of hospital stay, and short-term complications (within 30 postoperative days). Operation time was defined as the time from the first skin incision to skin closure. Postoperative complications were recorded during followup. Histopathological data such as radial border; total number of lymph nodes involved; pathological tumor, node, and metastasis; and differentiation were also recorded.

\section{Technical Information}

\section{Laparoscopic Surgical Technique}

The patient was placed on the operating table in a modified lithotomy position with the legs apart. The surgeon and camera assistant were positioned on the patient's left side. Insufflation was achieved by creating a 10-mm incision from the left lateral and bottom of the umbilicus with a Veress needle. Following exploration after placing a camera port at the same area, a 5-mm working port from the suprapubic area, a 10-mm working port from the left lower quadrant, and a 5-mm assistant port from the left upper quadrant 
were created. All procedures were performed with medial to lateral dissection. First, the ileocolic pedicle was placed in lateral traction, and the superior mesenteric vein (SMV) axis was reached. Next, the SMV was dissected to reach the superior mesenteric artery (SMA) margin, and the SMA was skeletonized from the right lateral side, over the SMV. The ileocolic artery and vein were dissected and clipped separately (Figure 1). Medial to lateral dissection was performed while preserving the retroperitoneal structures. The duodenum and pancreas were separated from the mesocolon by sharp dissection. The anterior superior pancreaticoduodenal vein was preserved and dissected in the Henle trunk. For tumors of the cecum and ascending colon, the right gastroepiploic arch was preserved, and the veins draining from the colon into the Henle trunk were clipped and separated. In hepatic flexure tumors, the right gastroepiploic vein was also clipped and cut. The middle colic was transected from its right branch for cecum and ascending colon tumors, but it was transected from its root for hepatic flexure tumors. In hepatic flexure tumors, the lymph nodes in the right side of the greater curvature and the infrapyloric lymph nodes were also included in the specimen. The mesentery was completely dissected at a distance of $10 \mathrm{~cm}$ from the proximal and distal end of the tumor. A median $6-\mathrm{cm}$ incision was made for extracorporeal anastomosis. The specimen was removed from a wound protector, and a double-layer ileocolic anastomosis was performed with 3-0 PROLENE and 3-0 PDS $^{\circledast}$ sutures. Intracorporeal anastomosis was performed in an isoperistaltic side-to-side fashion using a blue EndoGIA ${ }^{\oplus}$ laparoscopic stapler. The enterotomy line was closed with sutures or using a laparoscopic stapler. Following

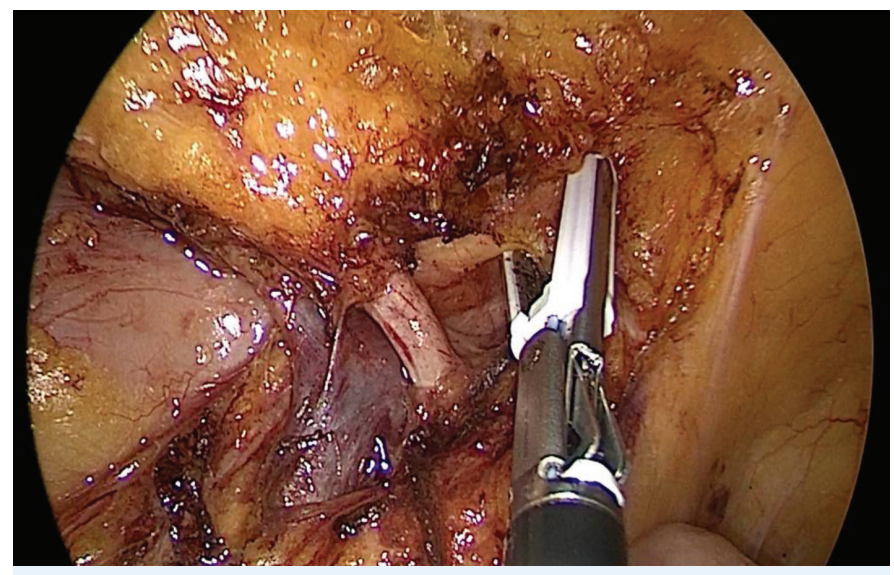

Figure 1. Laparoscopic complete mesocolic excision. The ileocolic artery crosses the SMV anteriorly.

SMV: Superior mesenteric vein intracorporeal anastomosis, the specimen was removed via a Pfannenstiel incision. A Jackson-Pratt silicone drain was placed to extend over both the SMV and anastomosis.

\section{Robotic Surgical Technique}

The DaVinci $X^{\circledR}$ surgical system (Intuitive Surgical, Inc., Sunnyvale, CA, USA) was used for operations. The patient was placed in the modified lithotomy position. Subsequently, four 8-mm trocars were positioned between the left midclavicular line and the right iliac spine for tumors of the cecum and ascending colon and in a more transverse fashion for hepatic flexure tumors in a linear line. A 12-mm assistant port was placed at the left lower quadrant. CME was performed similar to that in laparoscopic surgery (Figure 2). Unlike the intracorporeal anastomosis in laparoscopic surgery, the robotic port placed at the upper left quadrant was temporarily replaced with a $12-\mathrm{mm}$ port, from which anastomosis staples were fired (Figure 3). The enterotomy line was closed with a double-layer 3-0 STRATAFIX ${ }^{\circledR}$ suture (Ethicon Inc., USA). A Jackson-Pratt silicone drain was placed to extend over both the SMV and anastomosis.

\section{Statistical Analysis}

Data were analyzed using IBM SPSS Statistics program version 20. In the evaluation of data, distribution of the frequency (percentages and numbers) was used for categorical variables and descriptive statistics (median, minimum, and maximum) were used for numerical variables depending on the results of the Kolmogorov-Smirnov test for

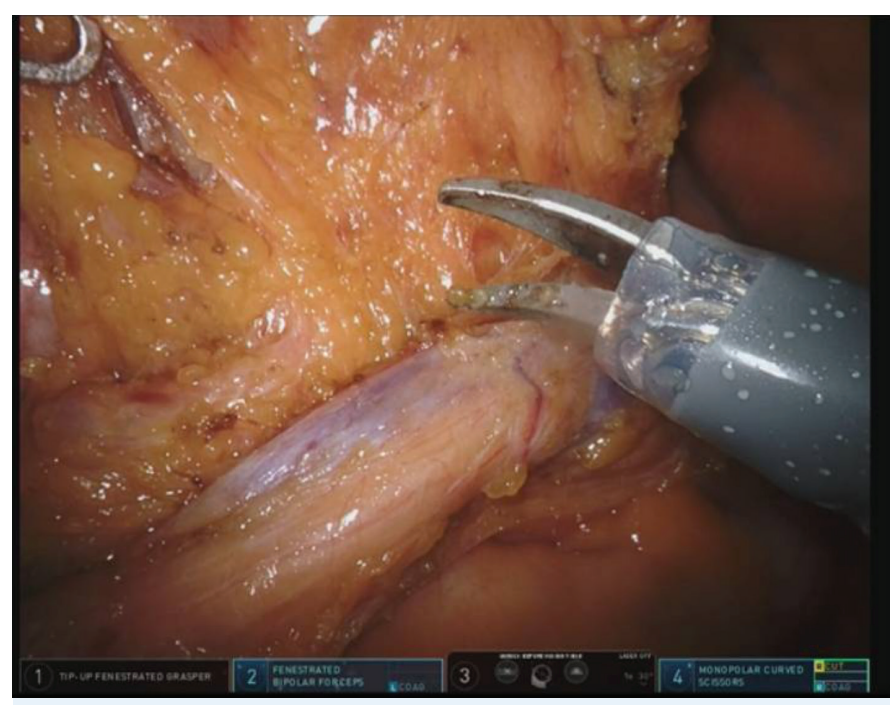

Figure 2. Lymph node dissection around the SMV (robotic complete mesocolic excision).

SMV: Superior mesenteric vein 
normal distribution. The Mann-Whitney $U$ test was used to perform comparisons between the two groups, and the chisquare test was used to examine the relationship between two categorical variables.

\section{RESULTS}

A total of 18 patients who underwent eight robotic and 10 laparoscopic right hemicolectomies with CME were included in the study. In the laparoscopic CME group, the mean age of the patients was $53.20 \pm 20.31$ years. Five patients were male. The median BMI was $30.20 \pm 6.25 \mathrm{~kg} / \mathrm{m}^{2}$. Moreover, three $(30 \%)$ tumors were localized in the cecum, two (20\%) in the ascending colon, three (30\%) in the hepatic flexure, and two (20\%) in the appendix. The ASA score was ASA I, II, and III in five, two, and three patients, respectively. The mean operation time was $227 \pm 56.184 \mathrm{~min}$. The median intraoperative bleeding volume was $70 \mathrm{ml}$ [minimum (min) maximum (max), 10-200 mL]. Anastomoses were performed with staplers in five patients using the extracorporeal method and in five patients using the intracorporeal method. The median length of stay in the hospital was 7 (min-max, 6-18) days. The median time of beginning oral intake postoperatively was 6 (min-max, 6-72) h. The median time of first flatus was 2 (range, 1-5) days.

In the robotic CME group, the mean age of the patients was $47.75 \pm 17.24$ years. Five patients were male. The median BMI was $26.25 \pm 4.65 \mathrm{~kg} / \mathrm{m}^{2}$. Four (50\%) tumors were localized in the cecum, three (37.5\%) in the ascending colon, and one

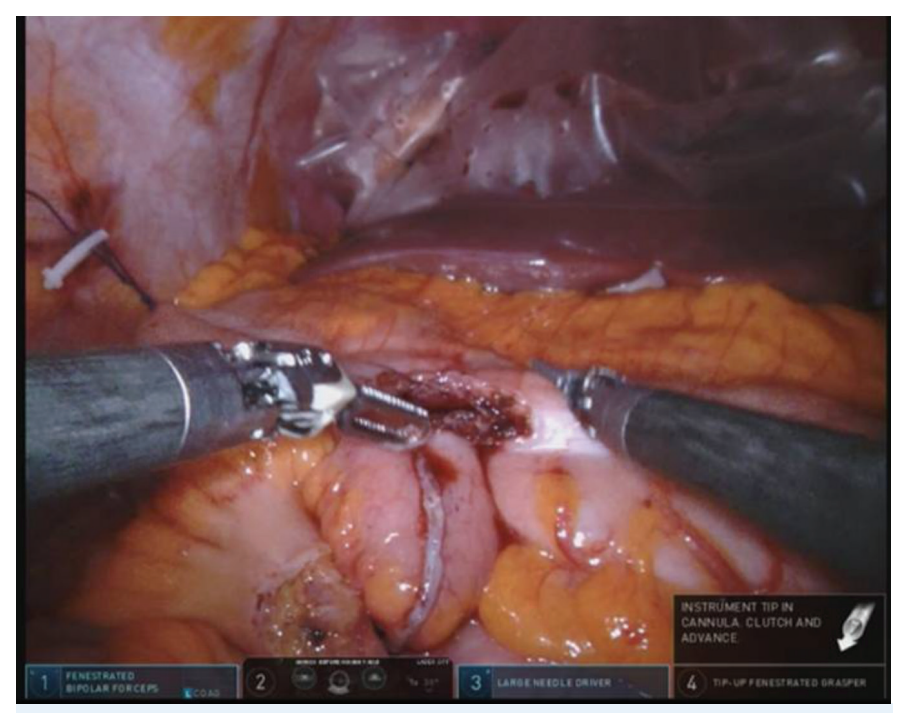

Figure 3. Appearance of the enterotomy line after ileocolic stapler anastomosis in robotic CME.

CME: Complete mesocolic excision
$(12.5 \%)$ in the hepatic flexure. Four patients had ASA I, and the other four had ASA II. The mean operation time was $283.75 \pm$ $50.62 \mathrm{~min}$. The median intraoperative bleeding volume was $110 \mathrm{ml}$ (min-max, 10-200 mL). Anastomoses were performed with staplers in three patients using the extracorporeal method and in five patients using the intracorporeal method. The median length of stay in the hospital was 11 (min-max, 2-25) days. The median time of beginning oral intake was 6 (min-max, 6-24) h. The median time of first flatus was 1 day (range, $1-5$ days).

With regards to the postoperative pathology results, welldifferentiated adenocarcinoma was noted in one patient, moderately differentiated adenocarcinoma in four patients, and poorly differentiated adenocarcinoma in two patients in the laparoscopic CME group. Two of the remaining three patients had appendix tumors, and no tumor was observed based on the pathology results of two patients (one had an appendix neuroendocrine tumor and the other had appendix mucinous neoplasia) who had undergone appendectomy. The remaining patient had a lesion with no lifting sign in the appendix orifice during endoscopy, which could not be removed endoscopically. The endoscopic biopsy revealed severe dysplasia, but the final pathology was adenocarcinoma in situ. When the T-stages of the pathological specimens were examined according to AJCC 8th edition, one patient was reported as having $T$ in situ, two patients had $T 2$, three patients had T3, two patients had T4a, and the other two patients had TO due to the absence of residual tumor after appendectomy. The mean total number of lymph nodes removed from the patients was $33.20 \pm 13.39$, with a median value of 29 (min-max, 19-60). Metastatic lymph nodes were present in only two patients, and each patient had five positive lymph nodes. The other eight patients had no metastatic lymph nodes.

In the robotic CME group, the postoperative pathology results were well-differentiated adenocarcinoma in one patient and moderately differentiated adenocarcinoma in seven patients. When the T-stages of the patients were examined according to AJCC $8^{\text {th }}$ edition, one patient had T4a and seven patients had T3. The mean total number of lymph nodes removed was $41.75 \pm 22.40$, with a median value of 37 (min-max, 1982).

No intraoperative complications were recorded in both the laparoscopic and robotic CME groups, and none of the patients had conversions to open surgery. Postoperative complications developed in five patients in the laparoscopic CME group. Wound infection developed in two patients, and 
the dose of low-molecular-weight heparin (LMWH) was increased based on the recommendation of the neurology department because one of the patients experienced transient ischemic attack on the third postoperative day. In one of the other patients, a chylous fistula was observed, and improvement was achieved with medical treatment [medium-chain triglyceride (MCT) diet]. One patient experienced hematochezia in the early postoperative period, and complete recovery was achieved with medical treatment by stopping treatment with LMWH. Finally, one patient developed atrial fibrillation with high ventricular response in the early postoperative period that was corrected with medical follow-up based on the recommendation of the cardiology department. Therefore, the beginning of oral intake time was prolonged in this patient.

In the robotic CME group, postoperative complications developed in four patients. Chylous fistula developed in two patients, and complete recovery was achieved with the MCT diet. The LMWH dose was increased in another patient due to the development of pulmonary thromboembolism in the early postoperative period. The patient was discharged following completion of treatment. Finally, a patient who was previously diagnosed with chronic obstructive pulmonary disease developed dyspnea and low saturation in the early postoperative period; the patient was followed up in the intensive care unit for 3 days based on the recommendation of the chest diseases department and was discharged with medical treatment. Therefore, the beginning of oral intake time was also prolonged in this patient.

No significant difference was found between the robotic and laparoscopic CME groups in terms of demographic data (i.e., age, sex, BMI, ASA, and tumor localization) (Table 1). With regard to the operative and postoperative data, no significant difference was found between the groups in the intraoperative bleeding volume, oral onset time, flatus time, number of metastatic lymph nodes, number of lymph nodes removed, and tumor grade, whereas the operation time of the robotic surgery group was longer than that of the laparoscopic group, and the difference was significant ( $p=$ 0.04) (Table 1).

\section{DISCUSSION}

The long-term positive effects of CME in the surgical treatment of colon cancer have recently been demonstrated. Although CME is relatively difficult to perform using the open surgical technique, the effects of its application using minimally invasive methods are still under investigation. A study reported that a larger number of lymph nodes and better specimen quality can be achieved with CME in terms of pathological examination, but it may cause intraoperative complications due to technical difficulties ${ }^{(9)}$. Because high volumes of open and minimally invasive oncologic surgeries (open CME and pancreaticoduodenectomy) are performed at our clinic, we believe that we have amassed vast experience of resection and vascular orientation above the SMV; therefore, we think that vascular injury and postoperative mesenteric ischemia are not encountered in the intraoperative period. We attribute the absence of conversion to open surgery in the 18 patients to the same reason.

No anastomotic leak was recorded in the 18 patients. In one patient in the laparoscopic CME group, hematochezia was observed after green cartridge stapler anastomosis. Intraluminal hemorrhage was considered from the anastomosis line, and it regressed spontaneously without colonoscopic intervention after the discontinuation of LMWH treatment. This event led the surgeon who later performed the operation to select the blue cartridge stapler for ileocolic anastomosis and colon transection.

Three of the 18 patients developed a chylous fistula. These patients were diagnosed with milky drainage and high triglyceride levels in the drain fluid after the oral regimen was started. When the video images of the two patients and the operation note of one patient were examined retrospectively, it was observed that the ileocolic artery crossed the SMV anteriorly. Ishiyama et al. reported that dissection over the SMA can be performed more easily in cases in which the ileocolic artery crosses anteriorly, and this anatomic situation provides an advantage over posterior crossing for long-term DFS ${ }^{{ }^{122}}$. Therefore, we think that if the ileocolic artery crosses anteriorly, the dissection above the SMA is wider; thus, chylous fistula is more common after easier apical dissection. No complications requiring interventional or surgical repeat intervention were observed in the 18 patients. Although the hospitalization period of the three patients with chylous fistula was 15, 19, and 25 days, their drainage decreased with the MCT diet. No other intraabdominal collection was observed after the drains were removed, and they continued their normal diet.

In this study, 12 patients did not have lymph node metastasis. In a previous study, Bertelsen et al. ${ }^{(13)}$ compared CME and non-CME patients and showed that the CME group was more advantageous in terms of DFS of stage 1 and stage 2 patients without lymph node metastasis. Therefore, we performed $\mathrm{CME}+$ apical lymph node dissection for patients with 
Table 1. Patient characteristics and intraoperative and postoperative findings

\begin{tabular}{|c|c|c|c|}
\hline & Robotic CME & Laparoscopic CME & $P$ value \\
\hline Mean age, SD & $47.75 \pm 17.24$ & $53.20 \pm 20.31$ & 0.555 \\
\hline \multicolumn{4}{|l|}{ Sex } \\
\hline Male & 5 & 5 & \multirow{2}{*}{0.596} \\
\hline Female & 3 & 5 & \\
\hline Mean BMI, SD & $26.25 \pm 4.65$ & $30.20 \pm 6.25$ & 0.157 \\
\hline \multicolumn{4}{|l|}{ ASA } \\
\hline I & 4 & 5 & \multirow{3}{*}{0.165} \\
\hline II & 4 & 2 & \\
\hline III & 0 & 3 & \\
\hline \multicolumn{4}{|l|}{ Tumor localization } \\
\hline Cecum & 4 & 3 & \multirow{4}{*}{0.531} \\
\hline Ascending colon & 3 & 2 & \\
\hline Hepatic flexure & 1 & 3 & \\
\hline Appendix & 0 & 2 & \\
\hline Mean operation time, SD & $283.75 \pm 50.62$ & $227 \pm 56.184$ & 0.04 \\
\hline $\begin{array}{l}\text { Median intraoperative hemorrhage } \\
\text { (min-max) }\end{array}$ & $110(10-200) \mathrm{mL}$ & $70(10-200) \mathrm{mL}$ & $p=0.672$ \\
\hline $\begin{array}{l}\text { Median oral intake time, } \mathbf{h} \\
\text { (min-max) }\end{array}$ & $6(6-24)$ & $6(6-72)$ & $p=0.478$ \\
\hline $\begin{array}{l}\text { Median first flatus, days } \\
\text { (min-max) }\end{array}$ & $1(1-3)$ & $2(1-5)$ & $p=0.237$ \\
\hline Tumor grade & & & \\
\hline Well differentiated & 7 & 1 & \\
\hline Moderately differentiated & 1 & 4 & $p=0.207$ \\
\hline Poorly differentiated & 0 & 2 & \\
\hline $\begin{array}{l}\text { Mean number of lymph nodes harvested, (SD) } \\
\text { (min-max) }\end{array}$ & $41.75 \pm 22.40(19-82)$ & $33.20 \pm 13.39$ & $p=0.329$ \\
\hline
\end{tabular}

negative lymph nodes in the preoperative examinations. The micrometastasis rate in patients with lymph node negativity increases up to 25\%-50\% when additional examination is performed. In addition, patients with micrometastasis, accepted as N0, have poorer long-term oncologic outcomes than NO patients without micrometastases (14). Therefore, we argue that CME and wide lymph node dissection should be performed in right colon malignancies. Furthermore, a higher number of dissected lymph nodes was reported in the CME group than in the non-CME group ${ }^{(15)}$. A study using SEER data reported that a high negative lymph node count and negative lymph node rate are prognostic factors for 5 -year OS in nonmetastatic colorectal cancer ${ }^{(16)}$. Therefore, we believe that the negative lymph node ratio is better with D3 dissection and the excess number of nonmetastatic lymph nodes is important oncologically.
In our series, three patients without malignancy underwent resection. The first patient had a wide-based polyp in the colon, had no lifting sign colonoscopically, and endoscopic pathology revealed a high-grade dysplasia that was staged as T2 on abdominal computed tomography. The postoperative pathology was reported as in situ carcinoma. The second patient had appendiceal mucinous neoplasia (30-mm in size) that spread to the base of the appendix. The third patient had a 25-mm diameter appendix NET with meso-appendix infiltration.

The operation time was significantly longer in the robotic CME group than in the laparoscopic CME group. We believe that the largest disadvantage of robotic surgery is the absence of a robot-compatible table during the operation, so the patient cannot be positioned and re- 
docking when repositioning is required. In laparoscopy, organ retraction and traction are mostly provided by gravity, and the procedure can be completed faster because patient positioning independent of the procedure and rapid switching of instruments are possible. Moreover, with laparoscopic surgery, the angle of view can be changed with a $30^{\circ}$ camera system. Although we use a $30^{\circ}$ camera in robotic surgeries, the angle of the horizontal plane needs to be changed because the camera only has a top and down angle of view, which may cause confusion. However, in robotic surgery, the console surgeon adjusts the camera angle and achieves stable traction using the $4^{\text {th }}$ arm. In contrast, robotic surgery enables continuous operations with three-dimensional imaging with depth perception, thereby minimizing tremors in long operations, and the arms can be moved in multiple planes. For this reason, robotic surgery appears to be more advantageous, especially during dissection of the SMV and Henle trunk.

Although the data are not shown, no difference was found between the minimally invasive and conventional groups in terms of the number of lymph nodes removed and the number of metastatic lymph nodes when compared with patients who underwent conventional CME in the same period ( $p=0.691$ and $p=0.502$, respectively). This may be the subject of another study. In the present patient series, no incidences of conversion, anastomotic leakage, or surgical mortality were observed, and these results show that minimally invasive CME can be safely performed at experienced centers.

This study has some limitations, including the lack of longterm oncological results, retrospective study design, lack of randomization among minimally invasive techniques, and low number of cases. Considering the short-term oncological outcomes, no difference was found between the groups in terms of the number of lymph nodes removed and circumferential resection margin negativity.

\section{CONCLUSION}

Based on our short-term follow-up, we believe that CME for right colon tumors can be safely performed robotically or laparoscopically without any disadvantage. Moreover, no significant difference was found between the two methods, except that robotic surgery had longer operation times. Nevertheless, care should be taken to reduce the risks of existing complications, and further studies are required to obtain long-term results.
Ethics Committee Approval: Ethics Committee approval was obtained from Ankara City Hospital.

Conflict of Interest: No conflict of interest was declared by the authors.

Financial Disclosure: The authors declared that this study received no financial support.

Etik Kurul Onayı: Ankara Şehir Hastanesi'nden Etik Kurul onay belgesi alındı.

Çıkar Çatışması: Yazarlar tarafından çıkar çatışması bildirilmemiştir.

Finansal Destek: Yazarlar tarafından finansal destek almadıkları bildirilmiştir.

\section{REFERENCES}

1. Heald RJ, Husband EM, Ryall RD. The mesorectum in rectal cancer surgery--the clue to pelvic recurrence? Br J Surg. 1982;69:613-6. doi: 10.1002/bjs.1800691019.

2. Nagtegaal ID, van de Velde CJ, van der Worp E, Kapiteijn E, Quirke P, van Krieken JH. Cooperative Clinical Investigators of the Dutch Colorectal Cancer Group. Macroscopic evaluation of rectal cancer resection specimen: clinical significance of the pathologist in quality control. J Clin Oncol. 2002;20:1729-34. doi: 10.1200/JC0.2002.07.010.

3. Xu J, Tian X, Chen Y, Ma Y, Liu C, Tian L, et al. Total mesopancreas excision for the treatment of pancreatic head cancer. J Cancer. 2017;8:3575-84. doi: 10.7150/jca.21341.

4. Cao B, Xiao A, Shen J, Xie D, Gong J. An optimal surgical approach for suprapancreatic area dissection in laparoscopic d2 gastrectomy with complete mesogastric excision. J Gastrointest Surg. 2020;24:916-7. doi: 10.1007/s11605-019-04467-8.

5. Akiyama Y, Iwaya T, Endo F, Nikai H, Sato K, Baba S, et al. Thoracoscopic esophagectomy with total meso-esophageal excision reduces regional lymph node recurrence. Langenbecks Arch Surg. 2018;403:967-75. doi: 10.1007/s00423-018-1727-5.

6. Hohenberger W, Schick CH, Göhl J. Mesorectal lymph node dissection: is it beneficial? Langenbecks Arch Surg. 1998;383:402-8. doi: 10.1007/ s004230050152.

7. Maslekar S, Sharma A, Macdonald A, Gunn J, Monson JR, Hartley JE. Mesorectal grades predict recurrences after curative resection for rectal cancer. Dis Colon Rectum. 2007;50:168-75. doi: 10.1007/s10350-006-0756-2.

8. Hohenberger W, Merkel S, Weber K. Lymphadenektomie bei Tumoren des unteren Gastrointestinaltraktes [Lymphadenectomy with tumors of the lower gastrointestinal tract]. Chirurg. 2007;78:217-25. (German) doi: 10.1007/s00104-007-1311-y.

9. Alhassan N, Yang M, Wong-Chong N, Liberman AS, Charlebois P, Stein $B$, et al. Comparison between conventional colectomy and complete mesocolic excision for colon cancer: a systematic review and pooled analysis: a review of CME versus conventional colectomies. Surg Endosc. 2019;33:8-18. doi: 10.1007/s00464-018-6419-2.

10. Gavriilidis P, Davies RJ, Biondi A, Wheeler J, Testini M, Carcano G, et al. Laparoscopic versus open complete mesocolic excision: a systematic review by updated meta-analysis. Updates Surg 2020;72:639-48. doi: 10.1007/s13304-020-00819-1.

11. Spinoglio G, Bianchi PP, Marano A, Priora F, Lenti LM, Ravazzoni F, et al.. Robotic versus laparoscopic right colectomy with complete mesocolic 
excision for the treatment of colon cancer: perioperative outcomes and 5 -year survival in a consecutive series of 202 patients. Ann Surg Oncol. 2018;25:3580-6. doi: 10.1245/s10434-018-6752-7.

12. Ishiyama Y, Maeda C, Shimada S, Kudo SE. Propensity-score-matched analysis of short- and long-term outcomes in patients with an ileocolic artery crossing anterior vs posterior to the superior mesenteric vein during curative resection for right-sided colon cancer. Surg Endosc. 2020;34:5384-92. doi: 10.1007/s00464-019-07333-5.

13. Bertelsen $C A$, Neuenschwander $A U$, Jansen JE, Wilhelmsen $M$, Kirkegaard-Klitbo A, Tenma JR, et al; Danish Colorectal Cancer Group. Disease-free survival after complete mesocolic excision compared with conventional colon cancer surgery: a retrospective, population-based study. Lancet Oncol. 2015;16:161-8. doi: 10.1016/S1470-2045(14)71168-4.
14. Rahbari NN, Bork U, Motschall E, Thorlund K, Büchler MW, Koch M, et al. Molecular detection of tumor cells in regional lymph nodes is associated with disease recurrence and poor survival in node-negative colorectal cancer: a systematic review and meta-analysis. J Clin Oncol. 2012;30:60-70. doi: 10.1200/JC0.2011.36.9504.

15. Yozgatli TK, Aytac E, Ozben V, Bayram O, Gurbuz B, Baca B, et al. Robotic complete mesocolic excision versus conventional laparoscopic hemicolectomy for right-sided colon cancer. J Laparoendosc Adv Surg Tech A. 2019;29:671-6. doi: 10.1089/Lap.2018.0348.

16. Pei JP, Zhang CD, Liang Y, Zhang C, Wu KZ, Zhao ZM, et al. Novel Nomograms Individually Predicting Overall Survival of Non-metastatic Colon Cancer Patients. Front Oncol. 2020;10:733. doi: 10.3389/ fonc.2020.00733. 